\title{
EVALUASI KEBIJAKAN PENETAPAN KOTA SERANG SEBAGAI IBU KOTA PROVINSI BANTEN (Studi Reformasi Birokrasi Pelayanan di Kecamatan Taktakan Kota Serang)
}

\author{
Rethorika Berthanilla ${ }^{1}$, Marthalena ${ }^{2}$, Arif Nugroho ${ }^{3}$ \\ ${ }^{1}$ Fakultas Ilmu Sosial, ilmu Politik dan Ilmu Hukum Universitas Serang Raya \\ ${ }^{2}$ Fakultas Ilmu Sosial, ilmu Politik dan Ilmu Hukum Universitas Serang Raya \\ ${ }^{3}$ Fakultas Ilmu Sosial, ilmu Politik dan Ilmu Hukum Universitas Serang Raya
}

\begin{abstract}
The implementation of bureaucratic reform of public services in public sector organizations in the sub-district has become a necessity in order to respond to the demands and dynamics of the people of Serang City. The purpose of this study was to analyze public service bureaucratic reforms in a number of villages in the Taktakan Subdistrict of Serang City in an evaluation of the policy to determine Serang City as the Capital of Banten Province. The research method used is a qualitative approach. Data collection techniques using observation and interviews with data analysis techniques through (1) data condensation (data condensation), (2) Presentation of data (display data), (3) withdrawal of conclusions (conclusion drawing). The results showed that the public service bureaucracy reforms of several villages in Taktakan Subdistrict of Serang City had not been carried out in accordance with the aspects of public service in accordance with the mandate of Law No. 25/2009 on Public Services, however, the application of the principles of evaluation of public services has been fulfilled, namely justice, public participation, accountability and transparency as well as efficiency and accessibility
\end{abstract}

Keywords: Determination of the City of Serang, Bureaucratic Reform, Public Services

\begin{abstract}
ABSTRAK
Penerapan reformasi birokrasi pelayanan publik pada organisasi sektor publik kecamatan menjadi suatu keniscayaan dalam rangka menjawab tuntutan dan dinamika masyarakat Kota Serang, hal tersebut menjadi salah satu instrumen evaluasi kebijakan penetapan Kota Serang sebagai Provinsi Banten. Tujuan penelitian ini adalah untuk menganalisis reformasi birokrasi pelayanan publik pada beberapa kelurahan di Kecamatan Taktakan Kota Serang dalam evaluasi kebijakan penetapan Kota Serang sebagai Ibukota Provinsi Banten. Metode penelitian yang digunakan adalah pendekatan kualitatif. Teknik Pengumpulan data menggunakan observasi dan wawancara dengan teknik analisis data melalui (1) kondensasi data (data condensation), (2)Penyajian data (display data), (3)Penyarikan kesimpulan (conclusion drawing). Hasil penelitian menunjukkan bahwa reformasi birokrasi pelayanan publik beberapa kelurahan di Kecamatan Taktakan Kota Serang masih belum dilaksanakan sesuai dengan aspek pelayanan publik sesuai dengan amanat UU No. 25/2009 tentang Pelayanan Publik meskipun demikian penerapan prinsip-prinsip evaluasi pelayanan publik sudah terpenuhi yaitu keadilan, partisipasi publik, akuntabilitas dan transparansi serta berdaya guna dan aksesbilitas.
\end{abstract}

\section{Kata Kunci : Penetapan Kota Serang, Reformasi Birokrasi, Pelayanan Publik}

*)Penulis Korespondensi

E-mail : marthalenamarthalena7@gmail.com 
Kolaborasi : Jurnal Administrasi Publik, Desember 2019 Volume 5 Nomor 3

\section{PENDAHULUAN}

Keberadaan kota sebagai pusat aktivitas masyarakat, fungsi pelayanan dan pusat administrasi pemerintahan akan terus tumbuh dan berkembang serta memberikan dampak sesuai dengan perubahan masyarakat. Suatu pusat kota harus memuat fungsi-fungsi diantaranya adalah pusat supply service, catering tourist, financial bussines, communication information, educational scientific, cultural entertainment, sport recreation social health protection, social political disamping fungsi sebagai pusat permukiman perkotaan untuk menjadi pusat kota (Mitkovi \& Dini, 2014)

Kota Serang yang berdiri sejak tahun 2007 secara regional dan nasional memiliki posisi geostrategis dalam pertumbuhan sosial dan ekonomi dengan dukungan infastruktur perhubungan darat berupa jalan to Jakarta-Merak dan sebagai pintu gerbang yang berbatasan langsung dengan perdagangan international di Laut Jawa.

Pembentukan Kota Serang sejalan dengan pembentukan Provinsi Banten yang pusat pemerintahannya terletak di Kota Serang sehingga Kota Serang otomatis ditetapkan menjadi ibukota Provinsi Banten sebagaimana tercantum dalam Undang-undang
Republik Indonesia Nomor 23 tahun 2000 tentang Pembentukan Provinsi Banten. Dalam perannya sebagai ibukota Provinsi Banten, Kota Serang memiliki beberapa fungsi diantaranya adalah fungsi politik dan ekonomi, fungsi sebagai pusat pemerintahan, fungsi diplomasi wilayah dengan wilayah lain.

Dengan berbagai fungsi yang dimiliki tersebut, Pemerintahan Kota Serang memiliki tuntutan dan tanggung jawab untuk terus meningkatkan penyelenggaraan pemerintahan terutama tata kelola pelayanan publik sebagai indikator pengukuran kelayakan Kota Serang sebagai ibukota Provinsi Banten.

Salah satu tuntutan keberhasilan pelayanan publik yang berorientasi kepada kesejahteraan masyarakat menjadi suatu keniscayaan sekaligus sebagai salah satu indikator pengukuran kelayakan Kota Serang sebagai Ibukota Provinsi Banten terutama penerapan dimensi pelayanan publik kelurahan dan kecamatan yang sesuai dan ideal dengan berpedoman kepada prinsip-prinsip good governance.

Tata kelola Pemerintahan Kota Serang terbagi menjadi enam kecamatan yaitu Kecamatan Serang, Kecamatan Taktakan, Kecamatan Cipocok, Kecamatan Curug, Kecamatan Walantaka dan Kecamatan Kasemen. 
Kolaborasi : Jurnal Administrasi Publik, Desember 2019 Volume 5 Nomor 3

Jenis pelayanan yang dilakukan oleh aparatur kecamatan diantaranya adalah pelayanan pengantar pembuatan Kartu Keluarga (KK), Pelayanan pengantar pembuatan Kartu Tanda Penduduk (KTP), Pelayanan pembutan Surat Keterangan Belum Nikah (SKBN), Pelayanan pembuatan Surat Keterangan Tidak Mampu (SKTM) pelayanan pembuatan surat keterangan tanda lapor diri (SKTLD).

Kecamatan sebagai bagian dari rantai birokrasi pemerintahan kabupaten /kota merupakan lembaga formal pemerintah yang menjalankan proses pemerintah dalam memberikan pelayanan kepada masyarakat umum. Oleh sebab itu mendorong penerapan reformasi birokrasi berbasis pelayanan publik yang sesuai dengan visi dan misi kecamatan adalah suatu keniscayaan. Pengembangan budaya baru yang sesuai dengan visi dan misi birokrasi sebagai agen pelayanan publik terus dilakukan (Dwiyanto, 2005). Hal tersebut menjadi harapan publik terhadap birokrasi pelayanan publik yang reformis dalam mengemban tugas dan tanggung jawab untuk melayani masyarakat dan bukan sebaliknya masyarakat yang melayani pemerintah.

Dalam hubungannya dengan konteks pelayanan publik, konsep reformasi birokrasi pemerintahan terdapat pada Undang-undang Nomor 5 Tahun 2014 tentang Aparatur Sipil Negara sebagai pengganti Undangundang Nomor 43 Tahun 1999 tentang Pokok-pokok Kepegawaian yang memfokuskan kepada peningkatan kualitas SDM birokrasi dalam upaya pemerintah yang baik dan bertanggungjawab. Beberapa kriteria birokrasi pemerintah yang diharapkan mampu melaksanakan reformasi birokrasi adalah : 1)Netral, yaitu mampu melayani semua lapisan masyarakat, tanpa memihak kepada suatu kekuatan politik tertentu; 2)Profesional, yaitu memiliki kompetensi sesuai dengan bidang pekerjaannya agar dapat melaksanakan tugas pokok dan tanggungjawabnya; 3)Berdaya guna dan berhasil guna, yaitu mampu menghasilkan sesuatu dengan sarana dan prasarana yang tersedia; 4)Transparan, yaitu mampu memberikan informasi tentang pemerintahan dan pembangunan kepada masyarakat; 5)Bebas korupsi, kolusi dan nepotisme yang dapat merugikan masyarakat; 6)Menjadi perekat persatuan dan kesatuan bangsa untuk menjaga keutuhan Negara Kesatuan Republik Idonesia.

Kecamatan Taktakan merupakan salah satu kecamatan di Kota Serang yang beberapa desanya sudah berubah 
Kolaborasi : Jurnal Administrasi Publik, Desember 2019 Volume 5 Nomor 3

status menjadi kelurahan dan berupaya mengimplementasikan reformasi birokrasi dalam aspek pelayanan pubik. Akan tetapi terdapat beberapa permasalahan yang menghambat reformasi birokrasi pelayanan tersebut seperti minimnya sumber daya manusia yang memiliki kompetensi dan keterampilan dengan basis pelayanan publik, masih rendahnya tingkat pelayanan yang terdapat di beberapa kelurahan antara lain Kelurahan Pancur, Kelurahan Kalang Anyar, Kelurahan Panggung Jati dan Kelurahan Sayar. Kemudian permasalahan lainnya adalah infrastruktur kantor kelurahan yang kurang representatif, rendahnya kinerja kepala kelurahan dan masih terdapat beberapa program-program kelurahan yang belum diimplementasikan.

Penelitian ini akan membahas tentang reformasi birokrasi pelayanan di Kecamatan Taktakan Kota Serang sebagai bagian dari evaluasi kebijakan penetapan Kota Serang sebagai Ibukota Provinsi Banten.

Berdasarkan amanat UU No. 25/2009 tentang Pelayanan Publik, Kementerian Pendayagunaan Aparatur Negara dan Reformasi Birokrasi (PANRB) melakukan pemantauan dan evaluasi kinerja penyelenggaraan pelayanan publik yang bertujuan untuk memberikan percontohan bagi unit penyelenggara pelayanan publik lainnya sekaligus mendorong pertumbuhan ekonomi dan memberi dampak bagi kesejahteraan masyarakat. Terdapat enam aspek pelayanan publik dimana masing-masing aspek memiliki bobot yakni kebijakan pelayanan publik $30 \%$, profesionalisme sumber daya manusia $18 \%$, sarana dan prasarana $15 \%$, sistem informasi pelayanan publik 15\%, mekanisme konsultasi dan pengaduan $15 \%$ serta inovasi pelayanan publik $7 \%$. Indikator penilaian diperoleh dari persilangan antara aspek dan lima prinsip dalam melakukan evaluasi. "Keadilan, partisipasi, akuntabilitas, transparansi, berdayaguna, dan aksesbilitas.

Pada aspek kebijakan pelayanan, penilaian akan melihat pada standar pelayanan yang disusun dan melibatkan masyarakat serta dipublikasikan, maklumat pelayanan, dan survei kepuasan masyarakat. Sedangkan untuk profesionalisme SDM, hal-hal yang perlu diperhatikan antara lain kompetensi SDM, kesigapan petugas, aturan perilaku dan kode etik, penghargaan dan sanksi, serta budaya pelayanan.

Untuk sarana dan prasarana melihat ketersediaan ruang parkir, fasilitas ruang tunggu, fasilitas pengguna layanan berkebutuhan khusus 
Kolaborasi : Jurnal Administrasi Publik, Desember 2019 Volume 5 Nomor 3

dan sarana penunjang lainnya. Sedangkan untuk Sistem Informasi Pelayanan Publik (SIPP), akan dilihat terkait pemanfaatan SIPP, pemilikan SIPP, dan pemutakhiran SIPP. Untuk media konsultasi dan pengaduan yang memiliki bobot penilaian 15\%, akan dilihat dari kelengkapan media yang digunakan. Sedangkan inovasi pelayanan publik. indikatror penilaian dari kemampuan terobosan untuk menangani permasahan pelayanan publik. indikator dan range nilai evaluasi pelayanan publik menggunakan indeks pelayanan publik. Nilai indeks tertinggi akan mencapai 4,51 - 5,00 dengan kategori A dengan predikat pelayanan prima artinya unit pelayanan publik sudah menerapkan seluruh aspek. Sementara untuk yang masuk ke kategori D - F, akan mendapatkan prioritas pembinaan.

\section{Definisi Reformasi Birokrasi} bukanlah sekedar perubahan struktur dan reposisi birokrasi, lebih dari itu reformasi birokrasi harus meliputi perubahan sistem politik dan hukum secara menyeluruh, perubahan sikap mental dan budaya birokrat dan masyarakat, serta perubahan mindset dan komitmen pemerintah serta partai politik (Prasojo \& Kurniawan, 2008).

$$
\text { Reformasi birokrasi perlu }
$$
dilakukan dalam rangka perubahan yang sesuai dengan tuntutan dan perkembangan masyarakat. Alasan untuk melakukan reformasi adalah dalam rangka: (1)merealisasikan pendekatan baru untuk menjalankan fungsi pelayanan publik yang lebih baik ke arah manajerial daripada sekedar administratif; (2)sebagai respon terhadap skala penanganan dan cakupan tugas pemerintah (3)perubahan dalam teori dan masalah ekonomi; dan (4)perubahan peran sektor swasta dalam penyelenggaraan pelayanan publik (Li, Dor, Deyo, \& Hughes, 2016).

Pelayanan publik adalah segala kegiatan pelayanan yang dilaksanakan oleh penyelenggara pelayanan publik sebagai upaya pemenuhan kebutuhan dan pelaksanaan ketentuan peraturan perundang-undangan. (M. Mahmudi dalam Sururi, 2019)

Penelitian tentang reformasi birokrasi pelayanan sudah dilakukan beberapa diantaranya adalah (Subanda, Putu, \& Prabawati, 2016; Wakhid, 2017; Suwandoko, 2018; Mason, 2014) Kemudian (Cordella, A; Tempini, 2015) dalam hasil penelitiannya mengemukakan bahwa penerapan informasi dan teknologi dapat dijadikan sebagai instrumen untuk mengurangi peran birokrasi dalam organisasi pemerintah. Selanjutnya penelitian (O'Flynn, 2010) menyatakan 
Kolaborasi : Jurnal Administrasi Publik, Desember 2019 Volume 5 Nomor 3

adanya model pemerintah kompetitif pasca birokrasi (yaitu manajemen publik baru) dan model pemerintah pasca birokrasi, pasca-kompetitif (yaitu nilai publik) dan mempertimbangkan implikasi bagi manajer.

Penelitian yang dilakukan oleh (Cruz Cesi, Keefer, 2015) menyatakan bahwa reformasi sektor publik di negara-negara berkembang perlu menekankan pentingnya kebijaksanaan politisi dalam mengatur jaringan dan relasi kekuasan untuk meminimalkan pengaruhnya dan mengoptimalkan legislatif untuk melakukan pengawasan terhadap eksekutif.

Berdasarkan beberapa hasil penelitian yang telah dipaparkan tersebut, maka dapat disimpulkan bahwa reformasi birokrasi pelayanan publik merupakan instrumen dalam rangka menjawab tuntutan dan dinamika masyarakat dan meningkatkan kompetensi sumber daya manusia pada organisasi sektor publik. Meskipun demikian, penelitian tentang studi reformasi birokrasi pelayanan publik pada organisasi sektor publik dalam evaluasi kebijakan penetapan kota sebagai ibukota provinsi belum dilakukan secara mendalam.

Tujuan penelitian ini adalah menganalisis reformasi birokrasi pelayanan publik pada beberapa kelurahan di Kecamatan Taktakan Kota Serang dalam evaluasi kebijakan penetapan Kota Serang sebagai Ibukota Provinsi Banten.

\section{METODE PENELITIAN}

Jenis penelitian yang digunakan dalam analisis ini adalah pendekatan kualitatif. Teknik Pengumpulan data menggunakan pengamatan langsung (direct observation) serta wawancara tidak terstruktur dan mendalam (unstructured or intensive interviewing) yang bertujuan untuk mendeskripsikan tentang bagaimana reformasi birokrasi pelayanan di Kecamatan Taktakan dalam konteks evaluasi kebijakan penetapan Kota Serang sebagai Ibukota Provinsi Banten. Penentuan informan pada penelitian ini menggunakan teknik purposive sampling Informan yang ditentukan teridiri dari Kepala Bagian Pemerintahan Kota Serang, Kepala Bappeda Kota Serang, Kelurahan Kalang Anyar, masyarakat kelurahan Kalang Anyar. Teknik analisis data dalam penelitian ini menggunakan model analisis data interaktif dari Miles Hubermen dan Saldana (2014). dengan langkah-langkah sebagai berikut : (1)kondensasi data (data condensation), (2)Penyajian data (display data), (3)Penyarikan kesimpulan (conclusion drawing). 
Kolaborasi : Jurnal Administrasi Publik, Desember 2019 Volume 5 Nomor 3

\section{HASIL DAN PEMBAHASAN}

Deskripsi pembahasan tentang evaluasi kebijakan penetapan Kota Serang sebagai Ibukota Provinsi Banten dengan fokus pada studi reformasi birokrasi pelayanan publik akan diuraikan melalui beberapa sub pok pembahasan dengan mengambil data penelitian di beberapa kelurahan Kecamatan Taktakan Kota Serang yaitu sebagai berikut :

\section{ASPEK PELAYANAN PUBLIK PADA ORGANISASI SEKTOR PUBLIK KELURAHAN}

\section{Kebijakan Pelayanan Publik}

Perubahan birokrasi dari Desa yang dipimpin oleh seorang Kepala Desa menjadi Kelurahan yang dipimpin oleh seorang Lurah di Kota Serang merupakan sebuah kebijakan reformasi birokrasi terhadap pelayanan publik yang tertuang dalam Peraturan Daerah Kota Serang Nomor 15 Tahun 2010 tentang tata cara pembentukan, penghapusan, penggabungan, pemekaran kelurahan dan perubahan status desa menjadi kelurahan.

Berdasarkan indikator penilaian keadilan dan akuntabilitas maka perubahan birokrasi tersebut memberikan dampak terhadap tata kelola pemerintahan kecamatan dalam melakukan fungsi pembinaan. Kepala
Desa dipilih oleh masyarakat yang tinggal di Desa tersebut dan dilantik oleh Walikota, sedangkan Lurah dipillih oleh Walikota dan dilantik juga oleh Walikota. Kepala Desa sudah barang tentu merupakan warga asli Desa tersebut sedangkan Lurah, tidak harus dari Desa tersebut melainkan diatur kembali oleh peraturan perundangundangan lainnya. Bila telah memenuhi standard maka dari daerah manapun (masih dalam Kota yang sama) bisa menjadi Lurah setempat.

Hal ini menjadi kendala tersendiri terutama untuk proses interaksi Non Formal antara Masyarakat dengan Lurah mereka. Dan mencerminkan lemahnya prinsip transparansi, berdaya guna dan aksesbilitas masyarakat. Berdasarkan hasil penelitian empiris, bahwa Lurah yang ditunjuk oleh pejabat terkait sering kali tidak dikenal oleh masyarakat setempat. Beberapa masyarakat yang tinggal di dekat kantor kelurahan, saat ditanya siapa nama Lurahnya pun mereka kesulitan untuk menjawab. Alasan yang dikemukan oleh mereka dikarenakan Lurah yang ditunjuk bukan dari Desa setempat.

Mereka hanya mengenal Lurah saat kegiatan Formal, seperti mengurus dokumen catatan sipil, jual beli, dll. Sehingga perlu adanya teknik tersendiri 
Kolaborasi : Jurnal Administrasi Publik, Desember 2019 Volume 5 Nomor 3

dari lurah yang ditunjuk untuk lebih dikenal oleh masyarakat Kelurahan sendiri.

Terlebih lagi, posisi Lurah terkadang dijabat oleh seorang Pelaksana tugas (Plt) yang di emban oleh seorang ASN di Kota atau tempat lainnya. Sudah barang tentu terjadi rangkap jabatan untuk oleh ASN tersebut. Hal ini berdampak pada kinerja yang tidak optimal untuk memimpin sebuah kelurahan. Hal ini juga menjadi perhatian dari masyarakat kelurahan tersebut, otomatis, posisi Plt tersebut tidak akan berlangsung lama.

\section{Profesionalisme Sumber Daya Manusia}

Aspek sumber daya manusia dalam sebuah organisasi pelayanan publik merupakan aspek yang sangat penting dalam sebuah organisasi sektor publik seperti kelurahan. Sumber daya manusia yang ada harus memiliki kualifikasi yang sesuai dengan kebutuhan dari sebuah organisasi. Kuantitas sumber daya manusia juga harus sesuai dengan volume kerja yang menjadi beban dari sebuah organisasi. Berdasarkan hasil penelitian empiris dari beberapa kelurahan di Kecamatan Taktakan Kota Serang diperoleh fakta bahwa profesionalisme sumber daya manusia ditunjukkan dengan sikap untuk tidak diskriminatif dalam memberikan pelayanan yang diberikan, semua masyarakat diperlakukan sama dan egaliter.

Meskipun demikian jumlah pegawai yang dimiliki masih sangat terbatas bila dibandingkan dengan volume kerja. Maka untuk mengatasi hal tersebut pihak kelurahan menggunakan tenaga honorer atau pegawai yang berstatus non PNS. Tentu hal ini tidak bisa dikatakan bahwa kelurahan kekurangan sumber daya manusia karena terdapat pegawai honorer, tetapi lebih tepatnya adalah kualifikasi pegawai yang tidak sesuai dengan kebutuhan organisasi. Tentu kondisi seperti ini akan mempengaruhi kinerja kelurahan secara keseluruhan.

Selain itu, hasil observasi penelitian terkait dengan tingkat kedisiplinan pegawai kelurahan masih rendah, ditandai dengan sering kali staff kelurahan bahkan Lurah tidak berada ditempat saat jam kerja. Staff ASN dan Honorer masih menjalankan kerja tidak sesuai dengan Tupoksi. Kemudian ditemukan rangkap jabatan untuk posisi Plt Lurah membuat tidak fokus dalam memimpin dan menjalankan program pemerintah dengan baik. Tentu hal ini akan mempengaruhi kualitas dalam memberikan pelayanan terhadap masyarakat sehingga prinsip-prinsip 
Kolaborasi : Jurnal Administrasi Publik, Desember 2019 Volume 5 Nomor 3

akuntabilitas dan berdaya guna tidak dapat diimplementasikan dengan baik.

\section{Sarana dan Prasarana}

Keberadaan sarana dan prasarana merupakan aspek penting organisasi sektor publik. Kinerja kelurahan akan optimal apabila didukung dengan ketersediaan sarana dan prasarana yang memadai dan mendukung kelancaran tugas dan tanggung jawab sumberdaya manusia dalam melakukan pelayanan publik.

Berdasarkan hasil penelitian, kondisi sarana dan prasarana masih belum optimal. Kondisi eksisting sarana dan prasarana hanya terbatas pada peralatan kerja yang dikategorikan cukup akan tetapi tidak didukung oleh ketersediaan sarana dan prasarana pendukung lainnya.

Kondisi eksisiting sarana dan prasarana seperti meja, komputer, lemari arsip belum memadai. Sedangkan sarana administrasi pemerintahan kelurahan seperti buku data peraturan kelurahan, buku data inventaris dan buku laporan pengaduan masyarakat belum tersedia. Kondisi tersebut

Minimnya ketersediaan sarana dan prasarana tersebut mengakibatkan pelayanan publik masih belum optimal sehingga prinsip berdaya guna dan aksesbilitas publik belum terpenuhi.

\section{Standar Pelayanan}

Berdasarkan hasil pengamatan peneliti dan wawancara kepada beberapa informan ditemukan bahwa Perubahan Status Desa menjadi Kelurahan memberikan nuansa yang berbeda dalam hal standard pelayanan.

Pada waktu status masih menjadi Desa, keperluan administrasi yang berhubungan dengan Desa dapat dilayani bukan hanya di Kantor Desa dan di jam Kantor saja melainkan bisa langsung kerumah Kepala Desa. Sedangkan disaat berubah status menjadi Kelurahan seluruh pelayanan administrasi yang terkait dengan Kelurahan dilayani di Kantor Kelurahan dan dalam jam kerja yang telah ditentukan. Transparansi dalam hal biaya administrasi, Kerja dan sebagainya terlihat jelas saat berubah status menjadi Kelurahan. Hal ini ditandai dengan dipasangnya spanduk "Tidak dipungut biaya" disetiap kantor kelurahan yang ditemui.

Hal ini menegaskan bahwa kala berstatus Desa praktik KKN menjadi hal yang biasa. Hal ini juga diperkuat dari keterangan beberapa informan yang diwawancarai di beberapa kelurahan bahwa budaya pungli sudah tidak lagi 
Kolaborasi : Jurnal Administrasi Publik, Desember 2019 Volume 5 Nomor 3

berlaku di beberapa kelurahan Kondisi tersebut dikarenakan dukungan partisipasi masyarakat dalam melakukan pengawasan cukup baik sehingga kinerja aparatur kelurahan dalam meminimalkan budaya tidak dipunguat biaya dalam setiap pelayanan yang diberikan dapat terwujud.

\section{Sistem Informasi pelayanan publik}

Aspek penting dalam penyelenggaraan sekaligus menjadi indikator evaluasi dan penilaian kinerja pelyanan publik adalah ketersediaan sistem informasi pelayanan yang transparan dan informasi sesuai dengan kebutuhan masyarakat.

Berdasarkan hasil penelitian dapat dikemukakan bahwa sistem informasi pelayanan publik yang tersedia di beberapa kelurahan Kecamatan Taktakan Kota Serang masih belum memadai, dalam hal ini sistem informasi yang diterapkan masih bersifat manual dan belum menerapkan sistem informasi kelurahan berbasis electronic government, hal ini disebabkan karena minimnya dana dalam menjalankan konsep digitalisasi pelayanan publik.

\section{Mekanisme Konsultasi Dan Pengaduan}

Bahwa pengaduan adalah pernyataan secara lisan atau tertulis atau ketidakpuasan pelanggan terhadap pelayanan yang diberikan oleh suatu sistem pelayanan. (Hadi, 2000:67-68). Dalam konteks ini, akses masyarakat untuk menyampaikan keluhan dan saran terkait dengan pelayanan publik yang diberikan menjadi indikator kinerja aparatur dan organisasi sektor publik.

Fakta empiris penelitian menunjukkan bahwa media informasi bagi masyarakat dalam menyampaikan konsultasi dan pengaduan sudah dilakukan dengan baik. Hal ini dapat dilihat dari adanya kegiatan sosialisasi yang dilakukan oleh aparatur kelurahan terhadap masyarakat melalui mekanisme pertemuan-pertemuan antara aparat kelurahan dengan masyarakat.

Tujuan yang ingin dicapai dalam kegiatan ini adalah terakomodasinya informasi-informasi dari masyarakat tentang pelayanan publik yang sudah diberikan sehingga menjadi bahan evaluasi bagi kelurahan untuk meningkatkan kinerja pelayanan publik.

\section{Inovasi Kebijakan Pelayanan Publik}

Prasyarat mutlak inovasi kebijakan publik adalah terwujudnya gagasan dan ide dari pejabat publik sebagai entry 
Kolaborasi : Jurnal Administrasi Publik, Desember 2019 Volume 5 Nomor 3

point diimplementasikannya berbagai program-program dan kebijakan. Gagasan dan ide dapat terealisasikan apabila organisasi sektor publik sebagai locus pembuatan kebijakan mampu melakukan adopsi dan adaptasi terhadap perkembangan yang terjadi di luar organisasi (Sururi, 2016).

Berdasarkan fakta penelitian dapat dikemukakan bahwa inovasi kebijakan pelayanan publik di beberapa kelurahan belum optimal dan stagnan. Minimnya gagasan dan ide dari aparatur kelurahan dalam melakukan inovasi menjadi salah satu faktor penyebab belum optimalnya inovasi kebijakan yang dilakukan.

\section{PRINSIP-PRINSIP EVALUASI}

\section{PELAYANAN PUBLIK}

\section{Keadilan}

Prinsip keadilan merupakan hal yang mendasar bagi publik untuk memeroleh pelayanan yang sebaikbaiknya. Dalam sendi-sendi pelayanan prima (Warella,1997:31) menyebutkan bahwa untuk menilai pelayanan publik yang berkualitas dapat digunakan kriteria-kriteria antara lain (1)Keadilan yang merata, yaitu bahwa caupan/ jangkauan pelayanan harus diusahakan seluas mungkin dengan distribusi yang merata dan diberlakukan.

Jika dikonfirmasi dengan hasil penelitian aspek pelayanan publik maka dapat disimpulkan bahwa prinsip keadilan sudah terpenuhi dan dilakukan oleh aparat beberapa kelurahan di Kecamatan Taktakan Kota Serang, seperti sikap profesional aparat untuk tidak diskriminatif dalam memberikan pelayanan yang diberikan, semua masyarakat diperlakukan sama dan egaliter.

Kemudian disebutkan bahwa bahwa ukuran komprehensif untuk servqual sektor publik antara lain fairness (keadilan), yaitu ukuran tingkat dimana masyarakat percaya bahwa pelayanan pemerintah disediakan sama untuk semua orang.

\section{Partisipasi Publik}

Mendorong peran serta masyarakat untuk berpartisipasi dalam penyelenggaraan pelayanan publik merupakan upaya bagi kelurahan untuk mengakomodir aspirasi dan kebutuhan masyarakat sekaligus menumbuhkan kreativitas dan inisiatif masyarakat. Keterlibatan warga dalam penyelenggaraan pelayanan publik berpeluang menjamin proses pelayanan publik menjadi akuntabel dan mampu memenuhi aspirasi pelayanan masyarakat (Dwiyanto, 2003)

Fakta penelitian bahwa dukungan masyarakat dalam melakukan 
Kolaborasi : Jurnal Administrasi Publik, Desember 2019 Volume 5 Nomor 3

pengawasan terhadap aparatur kelurahan untuk meminimalkan budaya tidak dipunguat biaya dalam setiap pelayanan yang diberikan menjadi salah satu indikator prinsip partisipasi sudah dilakukan.

\section{Akuntabilitas dan Transparansi}

Bahwa pelayanan publik harus dapat dipertanggungjawabkan sesuai dengan peraturan perundang-undangan, oleh sebab itu mendorong akuntabilitas kecamatan dalam implementasi pelayanan publik menjadim upaya yang berkelanjutan. Akuntabilitas menjadi faktor penting dari prinsip Good Governance sehingga aspek tersebut menjadi indikator pelayanan publik. Menurut Zeithaml dan Berry (2001) pelayanan publik itu harus dilaksanakan oleh birokrasi pemerintah dengan sebaik-baiknya, transparan, dan akuntabel agar tidak merugikan warga yang dilayani.

Hal tersebut sesuai dengan fakta penelitian bahwa transparansi dan akuntabilitas dalam penyelenggaraan pelayanan publik di beberapa kelurahan Kecamatan Taktakan Kota Serang sudah melaksanakan dengan baik. Hal ini dapat terlihat dari sistem informasi pelayanan publik dan mekanisme konsultasi dan pengaduan yang sudah dilakukan sesuai dengan standar operation procedure dan kemudahan publik dalam menyampaikan keluhan dan saran.

Transparansi dalam konteks penyelenggaraan pelayanan publik adalah terbuka, mudah, dandapat diakses oleh semua pihak yang membutuhkan serta disediakan secara memadai dan mudah dimengerti (Ratminto, Winarsih, 2005)

\section{Berdayaguna dan Aksesbilitas}

Prinsip berdaya guna dan aksesbilitas menjadi faktor penting tercapainya keberhasilan pelayanan publik. Masyarakat selaku pengguna pelayanan menjadi subjek pelayanan sehingga secara praktis dalam pelayanan publik ikut terlibat dan mendapatkan apresiasi untuk menggunakan hak pelayanan yang melekat.

Selain itu aksesbilitas masyarakat untuk mendapatkan pelayanan dapat dilakukan secara terbuka dan diberikan kesempatan yang luas sehingga masyarakat tidak mempunyai kesulitan dalam mengakses berbagai pelayanan yang diberikan.

Fakta empiris penelitian menunjukkan bahwa masyarakat sudah diperlakukan sebagai mitra dan subjek pelayanan, hal tersebut dapat dilihat dari kemudahan masyarakat dalam 
Kolaborasi : Jurnal Administrasi Publik, Desember 2019 Volume 5 Nomor 3

menyampaikan aspirasi terkait dengan permasalahan pelayanan yang belum optimal.

\section{KESIMPULAN}

Reformasi birokrasi pelayanan publik pada beberapa kelurahan di Kecamatan Taktakan Kota Serang dalam evaluasi kebijakan penetapan Kota Serang sebagai Ibukota Provinsi Banten dalam beberapa aspek masih perlu dilakukan evaluasi secara menyeluruh. Kebijakan pelayanan publik, keterbatasan sumber daya manusia dan sarana prasarana, sistem informasi pelayanan dan inovasi kebijakan pelayanan publik masih belum optimal sehingga memengaruhi pencapaian ketidakberhasilan indikator evaluasi dan kinerja pelayanan publik.

Meskipun demikian pemenuhan prinsip-prinsip evaluasi pelayanan publik seperi keadilan, partisipasi, transparansi dan akuntablitas, dan berdaya dan akesebilitas sudah terimplementasikan dengan baik meskipun masih diperlukan dukungan dari berbagai stakeholder untuk mencapai tingkat keberhasilanan pelayanan publik yang lebih optimal.

\section{DAFTAR PUSTAKA}

Buku

Hadi, Anwar. 2000. Sistem Manajemen
Mutu Laboratorium. Jakarta : Gramedia.

Miles,M.B, Huberman,A.M, dan Saldana,J. 2014.Qualitative Data Analysis, A Methods Sourcebook, Edition 3. USA: Sage Publications. Terjemahan Tjetjep Rohindi Rohidi, UI-Press

Ratminto dan Atik Septi Winarsih. 2005. Manajemen Pelayanan : Pengembangan Model

Zeithaml, V. A. Parasuraman, dan L. L. Berry. 2001. Melaksanakan Kualitas Pelayanan

\section{Jurnal}

Agus Dwiyanto. 2003. "Peran Masyarakat dalam Reformasi Pelayanan Publik". Jurnal Forum Inovasi, Vol. 8: SeptemberNopember 2003

Cordella, A; Tempini, N. (2015). E-?government and organizational change: Reappraising the role of ICT and bureaucracy in public service delivery. Government Information Quarterly.

Cruz Cesi, Keefer, P. (2015). Political Parties, Clientelism, and Bureaucratic Reform Political Parties , Clientelism, and Bureaucratic Reform Cesi Cruz*.

Li, S., Dor, A., Deyo, D., \& Hughes, D. R. (2016). The Impact of State Tort Reforms on Imaging Utilization. Journal of the American College of Radiology, 14(2), 149-156. https://doi.org/ 10.1016/j.jacr.2016.10.002

Mason, C. H. (2014). Administrative Decentralization - Bureaucratic Reform: Administrasi Publik, 11(April), 1-23. 
Kolaborasi : Jurnal Administrasi Publik, Desember 2019 Volume 5 Nomor 3

Mitkovi, P., \& Dini, M. (2014). City center organization and its influence on the city structure And Its Infulence On The City Structure. Architecture and Civil Engineering, (January 2004). https://doi.org/10.2298/FUACE040 $1041 \mathrm{M}$

O'Flynn, J. (2010). The Post Bureaucratic Model: Principles, Practices, Premises, 1-18.

Prasojo, E., \& Kurniawan, T. (2008). Reformasi Birokrasi dan Good Governance : Kasus Best Practices dari Sejumlah Daerah di Indonesia. In the 5 th International Symposium of Jurnal Antropologi Indonesia, Banjarmasin. 22-25 Juli 2008 (pp. 1-15).

Subanda, I. N., Putu, N. I., \& Prabawati, A. (2016). Organizational Restructuring Of Regional Apparatuses Of Denpasar Municipal Government To Achieve Bureaucratic Reform. Bisnis Dan Birokrasi Universitas Indonesia, 23(2).

Sururi, A. (2016). Inovasi Kebijakan Publik (Tinjauan Konseptual dan Empiris). Sawala, 4(3), 1-14.

Sururi, A. (2019). Jurnal natapraja. Natapraja Kajian Ilmu Administrasi Negara, 7(1), 105120.

Suwandoko, R. (2018). The Implementation of Bureaucratic Reform Pillars in Increasing Taxpayer Compliance at Semarang Tax Service Office compliance in the semarang tax service office ... ... JILS, 3(01), 5-28.
Wakhid adalah dosen Fakultas Ushuluddin UIN Raden Intan Lampung. TAPIs, 01(14).

\section{Laporan Penelitian}

Warella, Y. 1997.Administrasi Negara dan Kualitas Pelayanan Publik PidatoPengukuhan jabatan Guru Besar Madya ilmu Administrasi Negara.Universitas Diponegoro. Semarang.

\section{Dokumen Resmi}

Undang-undang Republik Indonesia Nomor 23 tahun 2000 tentang Pembentukan Provinsi Banten.

Undang-undang Nomor 5 Tahun 2014 tentang Aparatur Sipil Negara

Undang-undang No. 25/2009 tentang Pelayanan Publik

Peraturan Daerah Kota Serang Nomor 15 Tahun 2010 tentang tata cara pembentukan, penghapusan, penggabungan, pemekaran kelurahan dan perubahan status desa menjadi kelurahan

Wakhid, A. A. (2017). Ali Abdul 